\title{
РИСК КАК МЕРА ОПАСНОСТИ ДЛЯ ЖИЗНИ И ЗДОРОВЬЯ ЧЕЛОВЕКА В ХОДЕ ТУРИСТСКО-ЭКСКУРСИОННОГО ОБСЛУЖИВАНИЯ
}

\begin{abstract}
Кулинкович Марина Александровна, магистрант Мининского университета Крайнова Ольга Сергеевна, канд. экон. наук, дои., зав. кафедрой туризма филиал ЧОУВО «Московский университет им. С.Ю.Витте» в г.Нижнем Новгороде, г. Нижний Новгород
\end{abstract}

\begin{abstract}
Аннотация. В статье рассмотрены правовые аспекты действующего законодательства Российской Федерации в области обеспечения безопасности туризма. Даны понятия риск, приемлемый риск, а также рассмотрены виды рисков для жизни и здоровья человека в ходе туристско-рекреационного обслуживания и способы снижения степени риска.
\end{abstract}

Ключевые слова: риск, классификация рисков, приемлемый риск, способы снижения степени риска, обязанности туроператоров, туристский продукт.

Научный и практический интерес к проблемам риска и мероприятиям по их снижению обусловлен сложностью и вероятностным характером современных условий хозяйствования предприятий различных отраслей, но особенно актуальными эти вопросы становятся для сферы услуг. При обслуживании туристов на маршруте риск становится неотъемлемой частью деятельности туроператоров и поставщиков отдельных туристских услуг, в связи с чем возникает потребность 
совершенствования системы управления им, оформившейся в отдельную научно-практическую область - риск-менеджмента [5].

Рассмотрим особености вопросов учета отдельных видов риска при осуществлении туристско-экскурсионного обслуживания на маршруте.

Основным нормативным актом в области туризма является Федеральный закон от 24.11.1996 г. № 132-Ф3 (ред. 03.05.2012) «Об основах туристской деятельности в Российской Федерации [1]. В соответствии законом определен порядок осуществления туристской деятельности, в т.ч. обеспечение безопасности туризма, что в последнее время стал наиболее острым вопросом в туриндустрии. Наиболее подробно обеспечение безопасности туристов рассматривается в Национальном Стандарте Российской Федерации «Туристские услуги. Требования по обеспечению безопасности туристов. ГОСТ Р 50644-2009» [2]. В соответствие с действующим стандартом риск в туризме определяется как вероятность причинения вреда жизни и здоровью туристов, имуществу, окружающей среде, жизни и здоровью животных и растений с учетом тяжести этого вреда. Человек оценивает риски, осознавая страх перед смертью, получением травм, природными и социальными катаклизмами и др., т.о. риск служит мерой осознаваемой человеком опасности в его жизни и деятельности.

Туристская деятельность охватывает очень широкий спектр предоставляемых услуг (транспортировка, размещение, предоставление питания, экскурсионное обслуживание, спортивно-оздоровительные, лечебные и др. услуги) на предоставление которых, в свою очередь, оказывают существенное влияние множество факторов (природные, экономические, социальные, военно-политические факторы, эпидемии и др.), в связи с чем является одним из самых рискованных видов деятельности для жизни и здоровья человека [7].

К рискам в туризме относятся: травмоопасность, пожароопасность, гидрометеорологическая опасность, биологическая, 
экологическая, токсикологическая, радиоактивная, криминогенная, военно-политическая, психофизиологическая опасности, а также специфические риски.

К специфическим рискам относятся техногенные и природные катастрофы, чрезвычайные происшествия и ситуации, ненадлежащие состояние объектов материально-технической базы, сложные рельефы местности, непрофессиональный персонал, неподготовленность туристов к передвижению по маршруту, непредставлением или предоставлением неполной информации об условиях путешествия туристам (экскурсантам) [2].

Человек сталкивается с рисками в повседневной жизнедеятельности, оценивает вероятность их возникновения и принимает решения о необходимости тех или иных действий. Приемлемым может считаться риск, с которым общество готово мириться для получения определенных благ и выгод в результате своей деятельности. Обеспечение приемлемого уровня риска для жизни, здоровья и имущества туристов (экскурсантов) при совершении путешествий является необходимым условием оказания туристских услуг.

Осознание наличия многочисленных рисков при оказании туристских услуг побуждает туроператоров разрабатывать различные способы снижения степени риска. Способы снижения степени риска, обязательные для реализации в ходе оказания туристских услуг, закреплённые на законодательном уровне в Национальном Стандарте Российской Федерации «Туристские услуги. Требования по обеспечению безопасности туристов. ГОСТ Р 50644-2009» [2] представлены в таблице 1.

Таблица 1 - Способы снижения рисков для жизни и здоровья туристов в ходе туристско-экскурсионного обслуживания

\begin{tabular}{|l|l|}
\hline \multicolumn{1}{|c|}{ Риск } & \multicolumn{1}{|c|}{ Способы снижения риска } \\
\hline Травмоопасность & - установка защитных устройств и ограждений, \\
& - соблюдение туристами и обслуживающим персоналом \\
\hline
\end{tabular}




\begin{tabular}{|c|c|}
\hline & $\begin{array}{l}\text { правил проезда на транспортных средствах, } \\
\text { - использоваие средств индивидуальной защиты, соблюдение } \\
\text { требований эргономики к туристскому } \\
\text { снаряжению и инвентарю и правил их эксплуатации, } \\
\text { - соблюдение строительных норм и правил к средствам } \\
\text { размещения, нормативов, предъявляемых к транспортным } \\
\text { средствам, } \\
\text { - обязательное информирование туристов о факторах риска } \\
\text { получения травмы. }\end{array}$ \\
\hline Пожароопасность & $\begin{array}{llll}\text { - соблюдение } & \text { установленных } & \text { требований } & \text { пожарной } \\
\text { безопасности [3]. } & & & \end{array}$ \\
\hline $\begin{array}{l}\text { Гидрометеорологическая } \\
\text { опасность }\end{array}$ & $\begin{array}{l}\text { - выбор оптимального времени года и погодных условий тура, } \\
\text { - целесообразная разработка маршрута, } \\
\text { - установка в помещениях и транспортных средствах } \\
\text { кондиционерами, обогревателями, системами пожарной и } \\
\text { охранной сигнализациями, } \\
\text { - обеспечение туристов специальной экипировкой, } \\
\text { - своевременное информирование туристов о погоде на } \\
\text { маршруте, } \\
\text { - соотвествие микроклимата помещений и транспортных } \\
\text { средств действующим санитарно-эпидемиологическим нормам } \\
\text { и правилам [4]. }\end{array}$ \\
\hline Биологческая опасность & $\begin{array}{l}\text { - соблюдение установленных санитарно-эпидемиологических } \\
\text { норм и правил при оказании туристских услуг, а именно } \\
\text { применением оборудования и средств для дезинфекции, } \\
\text { дезинсекции, стерилизации, дератизации, } \\
\text { - использование знаков безопасности и необходимой } \\
\text { маркировки, } \\
\text { - своевременное проведение медицинских осмотров персонала, } \\
\text { - обязательное информирование туристов об опасности } \\
\text { местной флоры и фауны, } \\
\text { - предупреждение туристов о возникновении инфекционных } \\
\text { заболеваний и состоянии окружающей среды. }\end{array}$ \\
\hline Радиоактивная опасность & $\begin{array}{lcccc}\text { - } & \text { информирование } & \text { туристов } & \text { о воздействии } \\
\text { ультрафиолетового } & \text { и } & \text { других опасных } & \text { видов } \\
\text { на } & \text { человуека } & \text { и } & \text { способах использования средств }\end{array}$ \\
\hline
\end{tabular}




\begin{tabular}{|c|c|}
\hline & индивидуальной защиты. \\
\hline $\begin{array}{l}\text { Экологическая и } \\
\text { токсикологическая } \\
\text { опасность }\end{array}$ & $\begin{array}{l}\text { - соблюдение экологических и токсикологических норм и } \\
\text { правил, } \\
\text { - плановый и неплановый контроль содержания вредных } \\
\text { химических веществ в воздухе, воде, почве, продуктах питания } \\
\text { и других биологических средах, помещениях, транспортных } \\
\text { средствах. }\end{array}$ \\
\hline $\begin{array}{l}\text { Психофизиологическая } \\
\text { опасность }\end{array}$ & $\begin{array}{l}\text { - рациональное построением программ обслуживания } \\
\text { туристов, графиков перемещения по туристским маршрутам, } \\
\text { предусматривающих достаточные условия для нормальной } \\
\text { жизнедеятельности человека, } \\
\text { - учет психофизиологических особенностей туристов при } \\
\text { формировании туристской группы, } \\
\text { - соблюдение эргономических требований к используемым } \\
\text { туристским снаряжению и инвентарю и др. }\end{array}$ \\
\hline
\end{tabular}

При формировании и реализации туристского продукта туроператоры обязаны соблюдать нормы законодательства Российской Федерации позволяющие минимизировать риски для жизни и здоровья человека в ходе туристско-экскурсионного обслуживания, а именно:

- своевременно проводить анализ рисков для туристов;

- предоставлять гражданам необходимую достоверную и полную информацию о туристском продукте, обеспечивающую возможность его правильного выбора и безопасность на туристском маршруте;

- незамедлительно информировать ответственные органы Российской Федерации о происшествиях на маршруте;

- предоставлять туристам обязательное медицинское страхование и возможность дополнительного страхования;

- приостанавливать путешествие в случае возникновения риска, проводить эвакуацию пострадавших с места происшествия, в случае 
угрозы возникновения дополнительных рисков приостановить путешествие, обязательно обеспечивать инструктажи по безопасности.

Всё вышеперечисленное значительно снижает вероятность возникновения и причинения вреда жизни и здоровью туристов, и, в свою очередь, должно стать приоритетом в деятельности туроператоров.

Таким образом, современные условия развития индустрии туризма приводят к необходимости разработки новой стратегии управления деятельностью туроператоров, действующих в условиях риска, разработки методики анализа и оценки различных видов риска, а также процедур принятия и реализации управленческих решений для обеспечения безопасности туристского продукта и, соответственно, туриста при обслуживании на маршруте [5]. Кроме того, с позиции современного потребителя туристских услуг безопасность является важнейшим фактором выбора турпродукта, а значит, и фактором формирования спроса в индустрии, являющегося индикатором конкурентоспособности как отдельных туроператоров, так и туристских маршрутов [6].

\section{Список литературы:}

1. Об основах туристской деятельности в Российской Федерации: Федеральный закон от 24.11.1996 № 132-Ф3 (ред. от 03.05.2012) / Правовой сервер "Консультант Плюс" / [Электронный ресурс] // URL: http://www.consultant.ru/document/cons_doc_LAW_129632/ (дата обращения: 12.02.2015)

2. Национальный стандарт Российской Федерации «Туристские услуги. Требования по обеспечению безопасности туристов ГОСТ Р 506442009: Приказ Федерального агентства по техническому регулированию и метрологии от 15.12.2009 № 773-ст / Правовой сервер "Консультант Плюс" / [Электронный pecypc] // URL: http://base.consultant.ru/cons/cgi/online.cgi? req=doc;base=EXP; n=481763/ (дата обращения: 12.03.2015) 
3. Технический регламент о требованиях пожарной безопасности: Федеральный закон от 22.07.2008 N 123-Ф3 (ред. от 23.06.2014) / Правовой сервер "Консультант Плюс" / [Электронный ресурс] // URL: http://base.consultant.ru/cons/rtfcache/LAW159028_0_20150227_141640_5 3882.rtf/ (дата обращения: 12.03.2015)

4. Об утверждении СанПиН 2.1.2.2645-10 (вместе с "СанПиН 2.1.2.264510. Санитарно - эпидемиологические требования к условиям проживания в жилых зданиях и помещениях. Санитарноэпидемиологические правила и нормативы"): Постановление Главного государственного санитарного врача РФ от 10.06.2010 N 64 (ред. от 27.12.2010) / Правовой сервер "Консультант Плюс" / [Электронный pecypc] base.consultant.ru/cons/rtfcache/LAW111251_0_20150227_ 141640_53860.rtf/ (дата обращения: 12.03.2015)

5. Крайнова О.С. Инновационные аспекты разработки логистического подхода к управлению предприятиями индустрии туризма и гостеприимства: монография. Моск. ун-т им. С.Ю. Витте; ф-л Моск. ун-та им. С.Ю. Витте в г. Н. Новгород. М.: изд. «МУ им. С.Ю. Витте». 2015. 148 c.

6. Крайнова О.С., Лебедева Т.Е. Разработка и реализация целевых программ развития внутреннего и въездного туризма в Нижегородской области: потенциал для формирования конкурентоспособной туристской индустрии региона. Вестник Национальной академии туризма. 2014. №3 (31). С.37-40.

7. Крайнова О.С. Проблематика управления логистическими сервисными потоками предприятий индустрии туризма и гостеприимства / О.С.Крайнова. // В сборнике: Инновационные технологии управления. Всероссийская научно-практическая конференция. Нижний Новгород, 2014. C. 109-113. 